\title{
Evolutionary genetics of the insular lacertid lizard Podarcis tiliguerta: genetic structure and population heterogeneity in a geographically fragmented species
}

\author{
MASSIMO CAPULA* \\ Dipartimento di Biologia Animale e dell'Uomo, Università 'La Sapienza', Roma, Italy
}

\begin{abstract}
Podarcis tiliguerta is an insular Mediterranean lacertid lizard endemic to Corsica, Sardinia and many neighbouring small islands. The genetic structure and population heterogeneity of the species were studied by means of allozyme electrophoresis at 20 presumptive gene loci. The observed heterozygosity $\left(H_{\mathrm{o}}\right)$ decreases southwards towards more arid climatic regimes. No severe reduction in genetic variability was found in samples from the tiny satellite islands, except for a population inhabiting a very small island off the south-western coast of Sardinia (Meli Island), in which about 80 per cent of the genetic variability was lost. Population heterogeneity analysis carried out by the estimation of Wright's $F$-statistics demonstrated substantial genetic differentiation among populations. The value of $F_{\mathrm{ST}}(0.460)$ exceeds values known for other lizard species. $F$-statistics and genetic distance data show that genetic variation is distributed into three geographically coherent population groups. The first group includes populations from the northern part of the range (Corsica), the second includes populations from the small islands off the south-eastern coast of Corsica (Cerbicale and Lavezzi), and the third comprises populations from the southern part of the range (Sardinia and Meli Island). The pattern of genetic variability and the apparent clinal variation of alleles at a few loci (Idh-1, Gapd, Gpi) indicate that the subdivided genetic structure of $P$. tiliguerta is moulded by the interplay of stochastic processes and agents selectively affecting allele frequency changes.
\end{abstract}

Keywords: allozyme electrophoresis, population heterogeneity, genetic differentiation, gene flow, Podarcis tiliguerta, Lacertidae.

\section{Introduction}

Island species generally do not behave as single, infinitely large panmictic populations. This is because the species range is divided into ecologically diverse subranges, each with its own selective factors. In these species the pattern of genetic differentiation among subdivisions is influenced by the size of the subdivisions, by differences in the modes of selection among subdivisions, and by the degree of migration among them. Because these forces contribute to the deviation from Hardy-Weinberg proportions, at any moment population genetic structure can be

\footnotetext{
*Correspondence: Via F. Arena, 54, 00171 Roma, Italy.
}

described by measuring this deviation within populations and the amount of differentiation among populations (Wright, 1965, 1978). Although in recent years allozyme polymorphisms have been instrumental in studying the genetic structure of island populations on micro- and macrogeographical scales and in estimating the levels of gene flow between insular populations of various groups of organisms (see for example Koehn \& Eanes, 1978; Ayala, 1982; Berry, 1983; Selander \& Whittman, 1983; Larson et al., 1984), to date quantitative surveys focusing on the amounts of genetic variation in insular Mediterranean lacertid lizards (Lacertidae) are scarce (Gorman et al., 1975; Capula, 1990, 1994a), despite the fact that these reptiles are widespread and rather common. 
In this paper we use allozyme electrophoresis to estimate the distribution of genetic variation within and among populations, the genetic diversity and the level of gene flow in the insular Mediterranean lacertid lizard Podarcis tiliguerta. This species has been previously studied to evaluate its genetic divergence from some close relatives (Lanza et al., 1977; Mayer, 1981; Guillaume \& Lanza, 1982), but population genetic data are still lacking. Podarcis tiliguerta is a member of a lacertid genus that includes several species endemic to Mediterranean islands. It is a polytypic species found on Corsica, Sardinia and many neighbouring small islands (Arnold \& Burton, 1978). Podarcis tiliguerta is at an intermediate stage in the taxon cycle (Wilson, 1961) in that it has a complete pattern of distribution (no uninhabited islands) and shows strong interisland geographical variation in morphology and coloration (Lanza \& Poggesi, 1986).

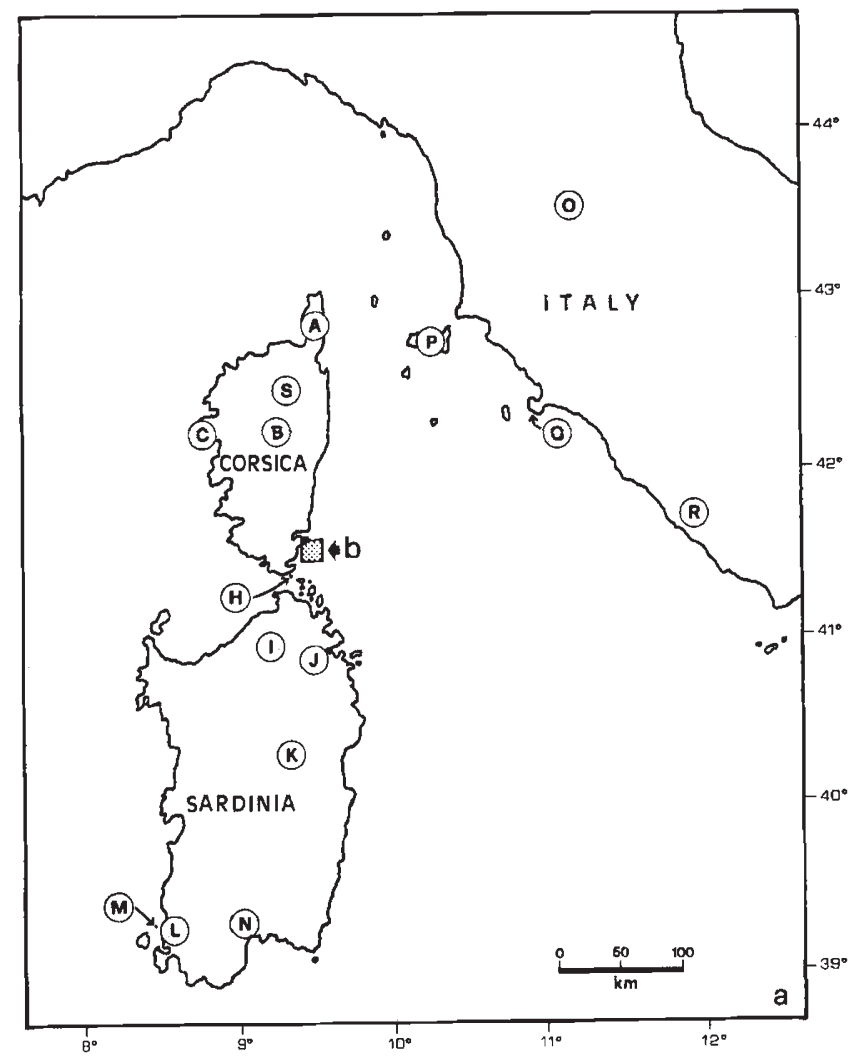

\section{Materials and methods}

\section{Sampling}

Samples of $P$. tiliguerta used in this study were obtained from 14 localities; three from Corsica, four from the Cerbicale Islands (SE Corsica), one from Lavezzi Island (S Corsica), five from Sardinia, and one from Meli Island (SW Sardinia). For interspecific comparison five samples of the closely related species $P$. muralis and $P$. sicula were also employed. The geographical origin and the number of specimens analysed per population are indicated in Fig. 1a,b.

To avoid killing animals or injurious biopsy, approximately $1 \mathrm{~cm}$ of the tail of each lizard was taken off following the suggestion by Mayer \& Tiedemann (1985). The piece of tail was then kept in Eppendorf reaction tubes $(2 \mathrm{~mL})$ and stored below $-70^{\circ} \mathrm{C}$ until electrophoretic analysis.

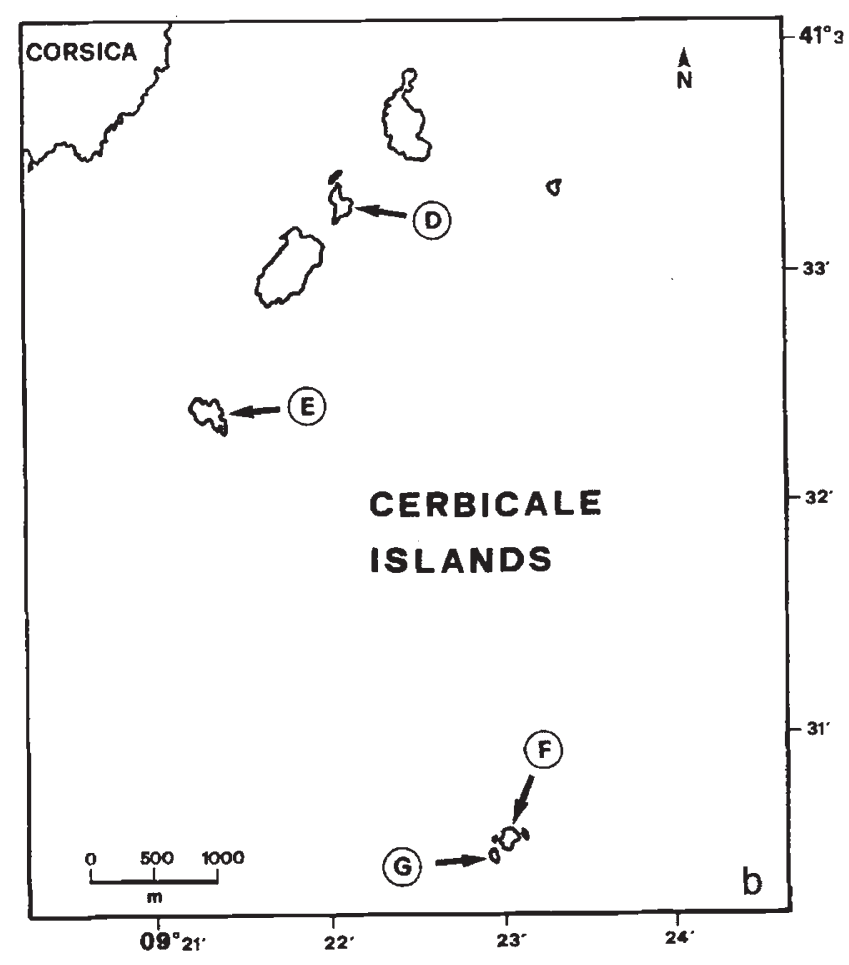

Fig. 1 Maps of Sardinia, Corsica, Italy (a) and Cerbicale Islands (b) showing sampling localities (sample size $(N)$ is given in parentheses). Podarcis tiliguerta: A, Sisco $(N=8)$; B, Vizzavona $(N=14) ; \mathrm{C}$, Cargèse $(N=12)$; $\mathrm{D}$, Maestro Maria $(N=8)$; E, Pietricaggiosa $(N=15) ; \mathrm{F}$, Toro Grande $(N=12)$; G, Toro Piccolo $(N=7) ; \mathrm{H}$, Lavezzi $(N=8) ; \mathrm{I}$, Tempio Pausania $(N=19)$; J, Olbia $(N=14)$; K, Nuoro $(N=7)$; L, Capo Giordano $(N=5)$; M, Meli $(N=7)$; N, Cagliari $(N=4)$; Podarcis muralis: O, Firenze $(N=15)$; P, Elba $(N=9)$; Q, Monte Argentario $(N=17)$; Podarcis sicula: R, Roma $(N=9)$; $\mathrm{S}$, Caporalino $(N=10)$. 


\section{Electrophoresis}

Standard horizontal starch gel electrophoresis was performed on tail muscle tissue; parts of this tissue were crushed in $0.1 \mathrm{~mL}$ of distilled water. Gene products for the following 20 presumptive enzyme loci were analysed: $\alpha G p d, L d h-1, L d h-2, M d h-1$, Mdh-2, Me-1, Me-2, Idh-1, Idh-2, 6Pgd, Gapd, Sod-1, Got-1, Got-2, Ck, Ak, Mpi, Gpi, Pgm-1, Pgm-2. The buffer systems used and electrophoretic procedures are given in Table 1. The staining techniques used were those described by Capula (1990).

Isozymes were numbered in order of decreasing mobility from the most anodal; allozymes were named numerically according to their mobility relative to the commonest one found in a reference population of $P$. sicula from Rome (Italy), indicated as $100(>100=$ faster mobility; $<100=$ slower mobility).

\section{Analysis}

Genotypic and allelic frequencies were determined by direct counts from allozyme phenotypes, and the resulting data were analysed by various statistical methods to describe the genetic structure of the $P$. tiliguerta populations. Genotypic proportions expected on the basis of Hardy-Weinberg equilibrium were calculated by Levene's (1949) formula for small samples. The statistical significance of departures from Hardy-Weinberg equilibrium was estimated using a test for calculating exact significance probabilities, analogous to Fisher's exact test (Haldane, 1954; Elston \& Forthofer, 1977). To determine whether the heterogeneity in the genotypic distribution reflects differences in allele frequencies, the variation in genic proportions among populations was subjected to a contingency $\chi^{2}$ analysis (Workman \& Niswander, 1970). The genetic variability of populations was estimated using the following parameters: mean number of alleles per locus $(A)$; proportion of polymorphic loci, at the 99 per cent level $(P)$; observed mean heterozygosity per locus $\left(H_{\mathrm{o}}\right)$; expected mean heterozygosity per locus $\left(H_{\mathrm{e}}\right)$ (unbiased estimate; Nei, 1978).

The distribution of genetic variation within and among populations was assessed using Wright's $F$-statistics (Wright, 1965, 1978). Statistical significance of Wright's standardized variance in allele frequencies $\left(F_{\mathrm{ST}}\right)$ was tested by the $\chi^{2}$ test: $\chi^{2}=2 N_{\mathrm{t}} F_{\mathrm{ST}}(k-1)$, with $(k-1)(s-1)$ degrees of freedom, where $N_{\mathrm{t}}$ is the total sample size, $k$ is the number of alleles, and $s$ is the number of subdivi- sions (Workman \& Niswander, 1970). A hierarchical analysis of population differentiation was also performed using the formulation of Wright (1978).

The genetic relationships among the populations studied were evaluated using Nei's (1972) standard genetic identity $(I)$ and standard genetic distance $(D)$. All genetic variability, $F$-statistics, and genetic distance measures were calculated by the computer program BIosys-1 (Swofford \& Selander, 1981).

To test the correlation between genetic and geographical distances, a Mantel test was used as advocated by Smouse et al. (1986). Tests were performed using the software NTSYs 1.50 (Rohlf, 1989).

Genotype data at 20 electrophoretic loci were analysed for rates of gene flow $(\mathrm{Nm})$ in $P$. tiliguerta populations. Quantitative estimates of $\mathrm{Nm}$ were derived using the indirect method of Wright (1978). In this method, assuming neutrality of the alleles studied and an equilibrium between genetic drift and migration in an infinite island model, $N m$ is related to $F_{\mathrm{ST}}$ by the formula $F_{\mathrm{ST}}=1 /(1+4 N m)$, where $N$ is the local population size and $m$ is the average rate of immigration.

An estimation of phenetic relationships among populations was obtained by generating a phenogram of all samples by means of the unweighted pair-group method with arithmetic averaging (UPGMA) based on the matrix of Nei's genetic distances (Sneath \& Sokal, 1973).

\section{Results}

\section{Pattern of variation}

Five of the 20 presumptive gene loci analysed ( 25 per cent) were found to be monomorphic and fixed for the same allele in all the samples studied $(\alpha G p d$, $M d h-2, \operatorname{Sod}-1, C k, A k)$. The allele frequencies at the other 15 variable loci are given in the Appendix. Six loci (30 per cent) were locally ( $\geq 5$ populations) and strongly polymorphic ( $L d h-1, M e-1,6 P g d$, Gapd, Got-1, Gpi). All other loci (45 per cent) were weakly polymorphic. As far as $P$. tiliguerta is concerned, the number of polymorphic loci was nine (26 alleles) in the populations from Corsica, six (21 alleles) in the populations from the Cerbicale and Lavezzi islands, and nine (29 alleles) in the samples from Sardinia and Meli Island. Four unique alleles (Slatkin, 1987) were detected in the Corsican populations, two in the populations from the Corsican satellite islands, and nine in the Sardinian populations (Fig. 2).

The results of the contingency $\chi^{2}$ analysis are given in Table 2 . The analysis reveals that ten out of 
Table 1 Enzymatic proteins examined and electrophoretic conditions employed

\begin{tabular}{|c|c|c|c|c|c|}
\hline Enzyme & $\begin{array}{l}\text { Migration } \\
+=\text { anodal } \\
-=\text { cathodal }\end{array}$ & $\begin{array}{l}\text { Buffer } \\
\text { system* }\end{array}$ & $\mathrm{V} / \mathrm{cm}$ & $\begin{array}{l}\text { Time } \\
(\mathrm{h})\end{array}$ & References \\
\hline $\begin{array}{l}\text { Glycerol-3-phosphate dehydrogenase } \\
\alpha \text { GPD (EC 1.1.1.8) }\end{array}$ & + & 3 & 8 & 6 & Ayala et al. (1972) \\
\hline $\begin{array}{l}\text { Lactate dehydrogenase } \\
\text { LDH (EC 1.1.1.27) }\end{array}$ & + & 4 & 7 & 6 & Brewer \& Sing (1970) \\
\hline $\begin{array}{l}\text { Malate dehydrogenase } \\
\text { MDH (EC 1.1.1.37) }\end{array}$ & + & 3 & 8 & 5 & Shaw \& Prasad (1970) \\
\hline $\begin{array}{l}\text { Malic enzyme } \\
\text { ME (EC 1.1.1.40) }\end{array}$ & + & 1 & 8 & 6 & Ayala et al. (1972) \\
\hline $\begin{array}{l}\text { Isocitrate dehydrogenase } \\
\text { IDH (EC 1.1.1.42) }\end{array}$ & + & 3 & 8 & 5 & Shaw \& Prasad (1970) \\
\hline $\begin{array}{l}\text { 6-Phosphogluconate dehydrogenase } \\
\text { 6PGD (EC 1.1.1.44) }\end{array}$ & + & 3 & 8 & 6 & Shaw \& Prasad (1970) \\
\hline $\begin{array}{l}\text { Glyceraldehyde-3-phosphate dehydrogenase } \\
\text { GAPD (EC 1.2.1.12) }\end{array}$ & + & 2 & 7 & 6 & Ayala et al. (1972) \\
\hline $\begin{array}{l}\text { Superoxide dismutase } \\
\text { SOD (EC 1.15.1.1) }\end{array}$ & + & 1 & 8 & 5 & Selander et al. (1971) \\
\hline $\begin{array}{l}\text { Glutamate-oxaloacetate transaminase } \\
\text { GOT (EC 2.6.1.1) }\end{array}$ & + & 3 & 9 & 6 & Selander et al. (1971) \\
\hline $\begin{array}{l}\text { Creatine kinase } \\
\text { CK (EC 2.7.3.2) }\end{array}$ & + & 1 & 8 & 5 & Ayala et al. (1972) \\
\hline $\begin{array}{l}\text { Adenylate kinase } \\
\text { AK (EC 2.7.4.3) }\end{array}$ & + & 1 & 8 & 5 & Ayala et al. (1972) \\
\hline $\begin{array}{l}\text { Mannose-6-phosphate isomerase } \\
\text { MPI (EC 5.3.1.8) }\end{array}$ & + & 2 & 8 & 4 & Harris \& Hopkinson (1976) \\
\hline $\begin{array}{l}\text { Glucose-6-phosphate isomerase } \\
\text { GPI (EC 5.3.1.9) }\end{array}$ & - & 3 & 8 & 6 & Selander et al. (1971) \\
\hline $\begin{array}{l}\text { Phosphoglucomutase } \\
\text { PGM (EC 5.4.2.2) }\end{array}$ & + & 4 & 8 & 6 & Brewer \& Sing (1970) \\
\hline
\end{tabular}

Enzymes are arranged by EnzymeCommission Number (EC).

*Buffer systems used: (1) Continuous Tris/citrate (Selander et al., 1971); (2) Tris/versene borate (Brewer \& Sing, 1970);

(3) Phosphate/citrate (Harris, 1966); (4) Tris/maleate (modified from Brewer \& Sing, 1970).

thirteen polymorphic loci exhibit statistically significant heterogeneity in the allele frequencies (see Table 2). This result indicates that there are highly significant differences among the gene pools of the $P$. tiliguerta populations, suggesting considerable local genetic differentiation. At three loci (Idh-1, Gapd, Gpi) displaying large differences in allele frequencies among populations, six alleles show significant departures from a random distribution (Sokal \& Oden's (1978) spatial autocorrelation analysis), indicating apparent clinal variation in allele frequencies. In the case of the Idh-1 locus, the $I d h-1^{108}$ allele is fixed in the populations from the Corsican satellite islands and Sardinia, decreasing in frequency towards the northern part of the range; $I d h-I^{102}$ is the predominant allele in the populations from Corsica. At the Gapd locus, where two electrophoretic alleles occur at high frequencies, i.e. Gapd $d^{94}$ and $\operatorname{Gapd}^{100}$, the Gapd $d^{100}$ allele predominates in the Corsican populations, whereas the Gapd $d^{94}$ allele is present at higher frequencies in most of the other samples. At the Gpi locus, two alleles occur at high frequencies: $G p i^{95}$ and $G p i^{103}$. The $G p i^{95}$ allele is nearly fixed in the populations from Sardinia, including Meli Island, and its frequency decreases towards the north, whereas $G p i^{103}$ is the predominant allele in the samples from Corsica and Corsican satellite islands (see Appendix). The alleles at the remaining loci exhibit random geographical patterns.

As to the diagnostic loci (at the 0.99 per cent level) between $P$. tiliguerta and the two other Podarcis species, four (20 per cent) displayed fixation of 


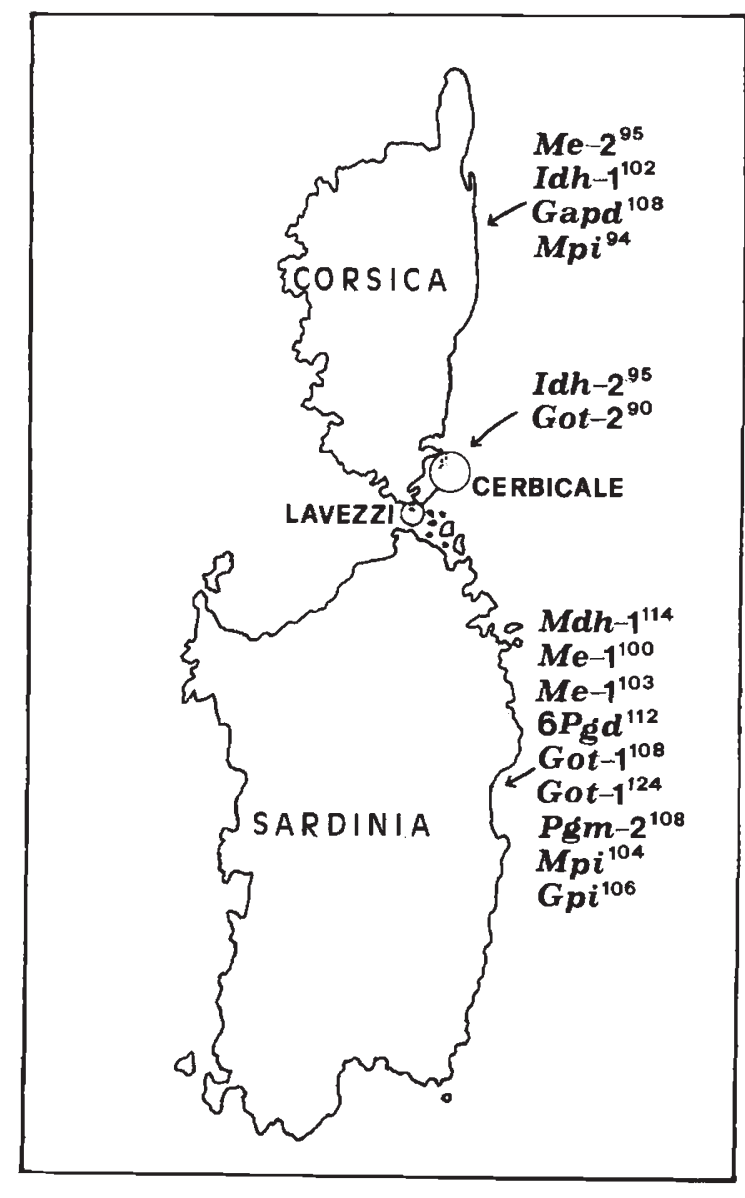

Fig. 2 Alleles specific to the Podarcis tiliguerta populations from Corsica, Corsican satellite islands (Cerbicale and Lavezzi), and Sardinia.

alternative alleles between $P$. tiliguerta and $P$. sicula (Idh-1, Got-1, Mpi, Gpi). Podarcis tiliguerta and P. muralis showed alternative alleles at two loci $(\mathrm{Mpi}$, $G p i)$ and highly differentiated allele frequencies at two further loci (Idh-1, Got-1). It must be noticed that two (Idh-1, Gpi) out of the four loci displaying fixation of alternative alleles among the three species also exhibit clinal variation in allele frequencies in $P$. tiliguerta populations.

Significant deviations from Hardy-Weinberg equilibrium in the direction of heterozygote deficiences were found for the following populations and loci (in parentheses): Vizzavona (6Pgd, $P<0.05)$; Pietricaggiosa (Got-2, $P<0.003)$; Olbia $(M e-1, P=0.001$; Gapd, $P<0.01)$.

\section{Genetic variability}

The measures of genetic variability used here are given in Table 3. The overall mean number of alleles
Table 2 Chi-square values resulting from contingency $\chi^{2}$ analysis at the polymorphic loci among populations of Podarcis tiliguerta

\begin{tabular}{lcrcc}
\hline Locus & $\begin{array}{c}\text { No. of } \\
\text { alleles }\end{array}$ & \multicolumn{1}{c}{$\chi^{2}$} & d.f. & $P$ \\
\hline Ldh-1 & 2 & 82.742 & 13 & $* *$ \\
Mdh-1 & 2 & 5.812 & 13 & NS \\
Me-1 & 4 & 135.780 & 39 & $* *$ \\
Me-2 & 2 & 59.222 & 13 & $* *$ \\
Idh-1 & 2 & 154.213 & 13 & $* *$ \\
Idh-2 & 2 & 46.746 & 13 & $* *$ \\
6Pgd & 3 & 87.274 & 26 & $* *$ \\
Gapd & 3 & 126.192 & 26 & $* *$ \\
Got-1 & 4 & 61.416 & 39 & $*$ \\
Got-2 & 2 & 21.321 & 13 & NS \\
Mpi & 3 & 64.021 & 26 & $* *$ \\
Gpi & 3 & 171.681 & 26 & $* *$ \\
Pgm-2 & 2 & 18.782 & 13 & NS \\
Total & & 1035.202 & 273 & $* *$ \\
\hline
\end{tabular}

d.f. $=$ degrees of freedom; ${ }^{*} P<0.01 ;{ }^{* *} P<0.001$; NS $=$ nonsignificant.

per locus in $P$. tiliguerta was 1.2 , ranging from 1.0 (Meli Island) to 1.5 (Tempio Pausania and Nuoro, Sardinia). The proportion of polymorphic loci $(P)$ showed a similar trend, ranging from 0.05 (Meli Island) to 0.35 (Tempio Pausania and Nuoro; Sardinia) and averaging 0.22 . The overall mean observed heterozygosity $\left(H_{\mathrm{o}}\right)$ was 0.066 and ranged from 0.007 (Meli Island) to 0.106 (Vizzavona, Corsica). The mean values of percent polymorphism $(P)$ and heterozygosity $\left(H_{0}\right)$ detected in the populations from the small Corsican islands $\left(P=0.20 ; H_{\mathrm{o}}=0.072\right)$ were similar to those found in the samples from Sardinia $\left(P=0.24 ; H_{0}=0.058\right)$. On the other hand, the samples from Corsica showed relatively higher values of average polymorphism and heterozygosity $\left(P=0.27 ; H_{\mathrm{o}}=0.090\right)$. The sample from Meli Island represents an exception, as it is characterized by a severe reduction in genetic variability $(P=0.05$; $H_{\mathrm{o}}=0.007$ ).

The levels of polymorphism and heterozygosity found in the samples of $P$. muralis $(P=0.35$; $\left.H_{\mathrm{o}}=0.059\right)$ were similar to the ones observed in $P$. tiliguerta, whereas little genetic variability was found in the samples of $P$. sicula $\left(P=0.05 ; H_{0}=0.015\right)$. This latter result is in agreement with those reported by Capula (1990, 1994a,b,c), who also found very low levels of percentage polymorphism and heterozygosity in several $P$. sicula populations from peninsular Italy and Sicily. 
Table 3 Genetic variability parameters in Podarcis tiliguerta populations

\begin{tabular}{|c|c|c|c|c|c|c|c|c|c|c|c|c|c|c|}
\hline \multirow{2}{*}{$\begin{array}{l}\text { Genetic } \\
\text { variability } \\
\text { parameters }\end{array}$} & \multicolumn{3}{|c|}{ Corsica } & \multicolumn{6}{|c|}{ Cerbicale Islands } & \multicolumn{5}{|c|}{ Sardinia } \\
\hline & A & B & $\mathrm{C}$ & D & $\mathrm{E}$ & $\mathrm{F}$ & G & $\mathrm{H}$ & I & $\mathbf{J}$ & $\mathrm{K}$ & $\mathrm{L}$ & M & $\mathrm{N}$ \\
\hline Mssl & 7.8 & 9.9 & 9.8 & 7.7 & 12.9 & 12.0 & 6.8 & 6.3 & 16.5 & 12.6 & 6.8 & 5.0 & 7.0 & 4.0 \\
\hline$A$ & 1.2 & 1.4 & 1.3 & 1.3 & 1.3 & 1.1 & 1.1 & 1.2 & 1.5 & 1.4 & 1.5 & 1.1 & 1.0 & 1.1 \\
\hline$P$ & 20 & 30 & 30 & 25 & 25 & 15 & 15 & 20 & 35 & 25 & 35 & 15 & 5 & 10 \\
\hline$H_{\mathrm{o}}$ & 0.063 & 0.106 & 0.101 & 0.081 & 0.072 & 0.042 & 0.073 & 0.093 & 0.082 & 0.041 & 0.100 & 0.030 & 0.007 & 0.038 \\
\hline (SE) & 0.031 & 0.044 & 0.038 & 0.040 & 0.033 & 0.027 & 0.046 & 0.044 & 0.037 & 0.020 & 0.042 & 0.016 & 0.007 & 0.027 \\
\hline$H_{\mathrm{e}}$ & 0.068 & 0.118 & 0.117 & 0.082 & 0.080 & 0.060 & 0.060 & 0.098 & 0.091 & 0.079 & 0.110 & 0.043 & 0.018 & 0.041 \\
\hline (SE) & 0.034 & 0.047 & 0.042 & 0.036 & 0.035 & 0.034 & 0.037 & 0.045 & 0.041 & 0.037 & 0.043 & 0.026 & 0.018 & 0.031 \\
\hline
\end{tabular}

Mssl, mean sample size per locus; $A$, mean number of alleles per locus; $P$, mean proportion of polymorphic loci; $H_{\mathrm{o}}$, observed mean heterozygosity; $H_{\mathrm{e}}$, expected mean heterozygosity (unbiased estimate; Nei, 1978) (SE, standard error). For geographical origin of populations see Fig. 1.

\section{Population heterogeneity}

Table 4 provides estimates of $F_{\mathrm{IS}}, F_{\mathrm{IT}}$ and $F_{\mathrm{ST}}$ among $P$. tiliguerta populations. Eight of the 13 single locus $F_{\mathrm{ST}}$ values were statistically significant, suggesting high genetic differentiation among populations. $F_{\text {ST }}$ values were high for the loci $L d h-1$ and $M e-1$, and noticeably high for the loci Idh-1 and Gapd, which exhibit alleles partially diagnostic between the populations from Corsica and the Corsican satellite islands, and Gpi, which displays significant differences in allele frequencies between the populations from Sardinia and those from Corsica and the Corsican islands. The mean $F_{\mathrm{ST}}$ value is 0.460 , indicating that 46 per cent of genetic variation in $P$. tiliguerta is attributable to differentiation among populations. As expected, the estimates of $F_{\mathrm{IT}}$ tend to mirror those of $F_{\mathrm{ST}}$, although there are discrepancies at certain loci. The mean $F_{\text {IT }}$ value was 0.488 , indicating a deficiency of heterozygotes within the species. $F_{\text {IS }}$ values are low (see Table 4 ), presumably because Hardy-Weinberg proportions are maintained within populations by random mating. Wright's (1978) hierarchical analysis combined across loci in all populations shows that 22 per cent of genetic differentiation (0.217) is attributable to divergence among the three population groups (Corsica, Corsican satellite islands, Sardinia). Genetic differentiation among populations within each group is slightly higher (0.257).

\section{Genetic distance}

Within $P$. tiliguerta, high values of genetic distance were found, $D$ ranging from 0.003 (between Maestro Maria and Toro Grande samples) to 0.199 (between Sisco and Cagliari samples), and averaging 0.071
Table 4 Summary of $F$-statistics at 13 loci for Podarcis tiliguerta populations

\begin{tabular}{lrrl}
\hline Locus & \multicolumn{1}{c}{$F_{\text {IS }}$} & \multicolumn{1}{l}{$F_{\text {IT }}$} & \multicolumn{1}{l}{$F_{\text {ST }}$} \\
\hline Ldh-1 & 0.117 & 0.430 & $0.355^{*}$ \\
Mdh-1 & -0.027 & -0.002 & 0.024 NS \\
Me-1 & 0.087 & 0.388 & $0.330^{*}$ \\
Me-2 & 0.556 & 0.661 & $0.236^{*}$ \\
Idh-1 & -0.080 & 0.731 & $0.751^{*}$ \\
Idh-2 & -0.333 & -0.018 & $0.236^{*}$ \\
6Pgd & 0.141 & 0.378 & $0.276^{*}$ \\
Gapd & -0.023 & 0.502 & $0.514^{*}$ \\
Got-1 & 0.077 & 0.191 & $0.123 \mathrm{NS}$ \\
Got-2 & 0.355 & 0.403 & $0.075 \mathrm{NS}$ \\
Mpi & 0.077 & 0.203 & $0.136 \mathrm{NS}$ \\
Gpi & -0.104 & 0.663 & $0.694^{*}$ \\
Pgm-2 & -0.077 & -0.005 & $0.067 \mathrm{NS}$ \\
Mean & 0.052 & 0.488 & 0.460 \\
\hline
\end{tabular}

Asterisk denotes statistical significance for $F_{S T}$ as determined by the $\chi^{2}$-test (see text).

${ }^{*} P<0.0001 ; \mathrm{NS}=$ nonsignificant.

across all populations. This is because (i) the samples from the Corsican satellite islands were genetically differentiated from those inhabiting the mother island (average $D=0.083$ ), and (ii) high intraspecific genetic distances were found comparing Sardinian (including Meli Island) populations with those from Corsica (average $D=0.113$ ) and from the small Corsican islands (average $D=0.077$ ). On the other hand, low values of standard genetic distance were found (i) among the five satellite Corsican islands (average $D=0.023$ ), (ii) within Corsica (average $D=0.046$ ), and (iii) within Sardinia (average $D=0.039$ ). However, these latter 


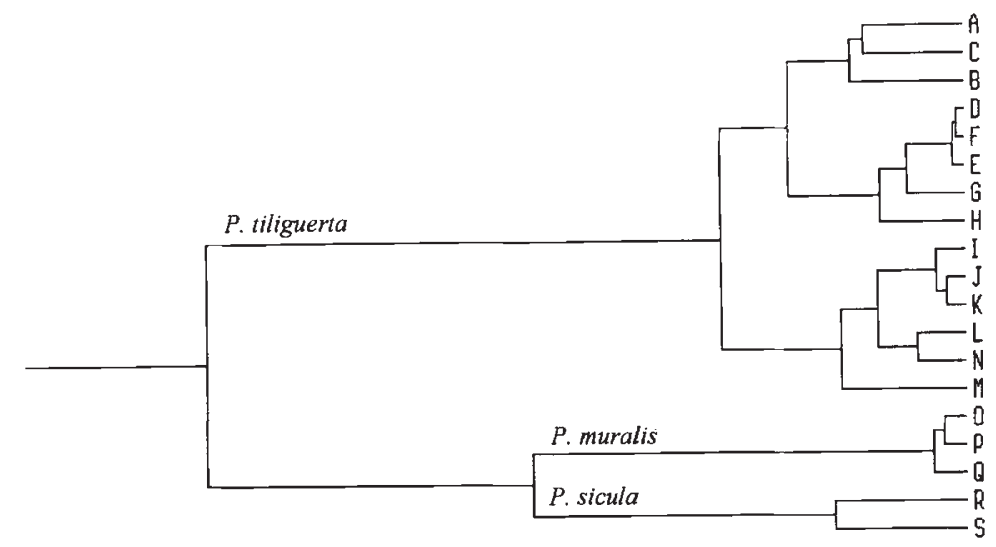

0.4 0.3
0.1
0.0 Nei's $D$
Fig. 3 Phenogram generated by UPGMA cluster analysis based on Nei's (1972) standard genetic distances among populations of Podarcis tiliguerta, $P$. muralis, and $P$. sicula (cophenetic correlation $=0.945$ ). For geographical origin of populations see Fig. 1. values were larger than those usually detected within the genus Podarcis among local populations of the same species (see for example Mayer, 1981; Capula, 1990, 1994a,b), indicating at least a certain amount of genetic subdivision for the populations inhabiting the major islands.

The comparison between genetic distances and geographical distances (Mantel test) reveals a positive correlation, significantly different from zero, for the total sample of $P$. tiliguerta (matrix correlation (normalized Mantel statistic): $r=0.629, P<0.004$ ).

As to the interspecific genetic distances, they ranged from $D=0.181$ to $D=0.318$, falling into the range obtained from comparisons between well recognized biological species of the genus Podarcis (Mayer \& Tiedemann, 1982; Capula, 1990, 1994a,c). Podarcis muralis, considered to be phylogenetically related to $P$. tiliguerta, appears to be remarkably differentiated from the latter $(D=0.300)$, and is more closely related to $P$. sicula $(D=0.181)$. On the other hand, the comparison between $P$. tiliguerta and $P$. sicula gave an average Nei's genetic distance $(D=0.318)$ very close to that found between the former species and $P$. muralis.

\section{Gene flow}

The rate of gene flow $(\mathrm{Nm})$ was calculated at various levels, from within each of the three major groups indicated by genetic distance data and cluster analysis to the total sample of $P$. tiliguerta. Estimates of $\mathrm{Nm}$ based on Wright's method are low; $\mathrm{Nm}$ among Sardinian samples is 0.500 , whereas when comparing Sardinian and Corsican samples $\mathrm{Nm}$ reduces to 0.284 . Rates of gene flow are slightly higher among the samples from Corsica $(N m=0.845)$, but $N m$ reduces to 0.435 when comparing the populations from Corsica with those from the Corsican satellite islands. The $\mathrm{Nm}$ value for the total sample of $P$. tiliguerta is 0.293 .

\section{Cluster analysis}

The genetic relationships among the populations studied are depicted in Fig. 3. The upgMA clustering procedure revealed three main clusters, corresponding to the three species analysed, in the phenogram constructed on the basis of the matrix of Nei's standard genetic distances. Within the cluster of $P$. tiliguerta, the existence of three subclusters should be noted. The first subcluster includes the populations from Corsica $(\mathrm{A}-\mathrm{C})$, the second contains the four samples from the Cerbicale Islands (D-G) and the sample from the Island of Lavezzi $(\mathrm{H})$, and the third includes the six populations from Sardinia (I-L, N) and Meli Island (M). Cophenetic correlation between the matrix of genetic distances and the derived phenogram was rather high (0.945).

\section{Discussion}

The results of our analyses on allozyme variation in $P$. tiliguerta indicate that genetic polymorphism is relatively high in this species. The level of heterozygosity $\left(H_{\mathrm{o}}=0.066\right)$ is larger than (i) the average estimated by Capula (1990) for nine species of Podarcis $\left(H_{\mathrm{o}}=0.053\right)$ and (ii) the average calculated by Nevo (1978) for 17 species of reptiles $\left(H_{\mathrm{o}}=0.047\right)$. The highest values of heterozygosity are found in the samples from Corsica, whereas the lowest ones are 
observed in some samples from Sardinia. The populations from the Corsican satellite islands are characterized by intermediate values of $H_{\mathrm{o}}$. This indicates that in $P$. tiliguerta $H_{\mathrm{o}}$ basically decreases southwards in the direction of both decreasing rainfall and increasing air temperatures. Although the lowest level of genetic variability was observed in a very small island (Meli), generally there was no significant correlation between island size and heterozygosity (Spearman's rank-correlation). Our data allow us to compare the genetic variability of 'parent' island populations with that of small island populations. In all, six small islands associated with two parent islands (Corsica, Sardinia) were sampled. None of the populations inhabiting the five small islands off the south-eastern coast of Corsica showed a markedly reduced genetic variability compared with that of the parent island, i.e. the so-called 'small island effect' (Gorman et al., 1975). The levels of polymorphism and heterozygosity detected either on the larger (Lavezzi, $0.729 \mathrm{~km}^{2}$; Pietricaggiosa, $0.046 \mathrm{~km}^{2}$ ) or on the tiny satellite islands (Maestro Maria, $0.028 \mathrm{~km}^{2}$; Toro Grande, $0.016 \mathrm{~km}^{2}$; Toro Piccolo, $0.005 \mathrm{~km}^{2}$ ), although lower than those found on Corsica $\left(P=0.20\right.$ vs. $P=0.27 ; H_{0}=0.072$ vs. $H_{\mathrm{o}}=0.090$ ), were more than we might expect from the size of these small islands (see for example Gorman et al., 1975; Gorman \& Kim, 1976; Guillaume \& Lanza, 1982; Capula, 1994a,c). Moreover, these populations were genetically differentiated from those inhabiting Corsica (average Nei's $D=0.083$ ). As the Cerbicale Islands are geographically very close to Corsica ( $\simeq 3 \mathrm{~km}$ from Punta Cerbicale, SE Corsica), the possibility of several arrivals of lizards from the parent island via passive transport cannot be excluded. Such arrivals could explain the preservation of the relatively high genetic variability observed in the samples from these small islands. A different situation is found in the sample from Meli Island (SW Sardinia), which is characterized by a severe reduction in genetic variability compared with that observed in the populations from the parent island. This could be caused by genetic drift phenomena, as supported by the fact that this population (i) inhabits a tiny fringing island $\left(<0.01 \mathrm{~km}^{2}\right)$, (ii) has no unique alleles and is characterized by a predominance of fixed alleles at each locus, (iii) is genetically very similar (Nei's $D=0.029)$ to the geographically closest population $(\simeq 1 \mathrm{~km})$ from Capo Giordano (SW Sardinia) (Fig. 1).

The genetic heterogeneity analysis demonstrates substantial genetic differentiation among local populations of $P$. tiliguerta, with the level of genetic subdi- vision exceeding values known for other lizard species (McKinney et al., 1972; Sites \& Greenbaum, 1983; Sarre et al., 1990). The estimated standardized variance in gene frequency $\left(F_{\mathrm{ST}}\right)$ for the total sample is highly significant, with a value $(0.460)$ much higher than that calculated by Capula (1994a) for the insular lacertid lizard $P$. wagleriana $\left(F_{\mathrm{ST}}=0.153\right)$ and very high for vertebrates in general (see for example Gorman et al., 1975; Wright, 1978; Schonewald-Cox et al., 1983; Ragghianti \& Wake, 1986). This indicates that 46 per cent of the gene diversity was between populations, and 54 per cent was within populations.

$F$-statistics and genetic distance data show that, at the scale of the study, genetic variation in $P$. tiliguerta is distributed into three population groups. These groups are geographically coherent, as indicated by UPGMA cluster analysis (Fig. 3). The first group includes the populations from the northern part of the range (Corsica), the second includes the populations from the small islands off the south-eastern coast of Corsica (Cerbicale and Lavezzi), and the third comprises the populations from the southern part of the range (Sardinia and Meli Island). Genetic distances found among the three population groups are much higher than those usually detected within the genus Podarcis among local populations of the same species (see Mayer, 1981; Capula, 1990, $1994 a, b, c)$, the average Nei's $D$ values ranging from 0.077 to 0.113 . On the other hand, these values fall below those normally encountered comparing populations of well recognized biological species (Thorpe, 1983), as showed by the comparison with $P$. muralis and $P$. sicula samples (Fig. 3).

Several conditions may be responsible for population structuring and differentiation in the geographically fragmented $P$. tiliguerta, such as the occurrence of genetic drift phenomena, the influence of different selective regimes, and the mode and level of gene flow. Although the distribution of genetic diversity among $P$. tiliguerta populations appears to be random at most loci within the area studied, and genetic drift might account for the possible loss of alleles in the populations inhabiting the smallest fringing island (Meli Island), this in no way implies that alleles at all loci are behaving neutrally and that differentiation can occur only by genetic drift. The hypothesis that different selective regimes actively favour different alleles, at least at a few loci, cannot be excluded. The latter possibility is supported by the observation that genetic differentiation among populations results mainly from large differences in allele frequencies at a few loci (Idh-1, Gapd, Gpi). Marked differentiation at these loci may be the 
result of range fragmentation produced by late Pleistocene geological events, when Sardinia, Corsica, and the other small satellite islands (linked to each other until the last phase of the Würmian glacial period (Caloi et al., 1988)) were physically separated by sea channels resulting from marine ingression (Lanza, 1972, 1983). However, because the alleles at the Idh-1, Gapd and Gpi loci show significant departure from random distribution and appear to vary clinally across the populations studied, it is possible that most of the polymorphisms at these loci are being selected.

Reduced gene flow is another important factor promoting genetic differentiation between geographically isolated populations (Slatkin, 1987). Therefore we expected to find a relatively high correlation between geographical and genetic distances and low or very low levels of gene flow among the three population groups in this study. The results of our analyses are congruent with these expectations, as we found a positive and significant correlation between genetic and geographical distances. This correlation is an expression of isolation by distance at the scale of the study. Moreover, the rates of gene flow among the three groups of populations are noticeably low ( $\mathrm{Nm}$ ranging from 0.284 to 0.435 ), indicating highly significant independence of local demes. It must be stressed that when the estimated average number of migrants per generation $(\mathrm{Nm})$ is $<0.5$, local demes are supposed to be largely unconnected under any model of gene flow (Nagylaki, 1983). This situation corresponds well to the case of the island model of population differentiation (Wright, 1940, 1943), in which strong isolation and large genetic differences among populations are involved.

In summary, the genetic structure of $P$. tiliguerta appears to be more subdivided than that of other lizards studied to date. Although gene diversity analysis cannot provide much information about the relative significance of selectionist or neutralist causes of this subdivision, the pattern of genetic variability and the apparent clinal variation of alleles at some loci suggest that the genetic structure of populations is moulded by the interplay of stochastic processes (geographical isolation, genetic drift) and agents selectively affecting allele frequency changes (local bioclimatic regimes).

\section{Aknowledgements}

This study was a part of the dissertation thesis of the author. The author thanks L. Bullini and G. Nascetti, who provided facilities, financial support and assistance during the electrophoretic analysis, B. Lanza, who kindly provided some of the specimens of $P$. tiliguerta utilized in this study, and two anonymous reviewers for suggesting valuable improvements in the manuscript.

\section{References}

ARnOld, E. N. AND Burton, J. A. 1978. A Field Guide to the Reptiles and Amphibians of Britain and Europe. Collins, London.

AYALA, F. J. 1982. The genetic structure of species. In: Milkman, R. (ed.) Perspectives on Evolution, pp. 60-82. Sinauer Associates, Sunderland, MA.

AYAlA, F. J., POWEll, J. R., TRACEY, M. L., MOURĀO, C. A. AND PÉREZ-SALAS, S. 1972. Enzyme variability in the Drosophila willistoni group. IV. Genic variation in natural populations of Drosophila willistoni. Genetics, 70, 113-139.

BERRY, R. J. 1983. Diversity and differentiation: the importance of island biology for general theory. Oikos, $\mathbf{4 1}$, $523-529$.

BREWER, G. J. AND SING, C. F. 1970. An Introduction to Isozyme Techniques. Academic Press, New York \& London.

CALOI, L., KOTSAKIS, T. AND PALOMBO, M. R. 1988. La fauna a vertebrati terrestri del Pleistocene delle isole del Mediterraneo. Bull. Ecol., 19, 131-151.

CAPUlA, M. 1990. Ricerche sulla Struttura Genetica di Podarcis sicula, P. wagleriana e P. filfolensis (Reptilia: Lacertidae): Aspetti Tassonomici ed Evolutivi. Ph.D. Thesis, Università degli studi di Bologna, Bologna.

CAPULA, M. 1994a. Genetic variation and differentiation in the lizard, Podarcis wagleriana (Reptilia: Lacertidae). Biol. J. Linn. Soc., 52, 177-196.

CAPUlA, M. 1994b. Population genetics of a colonizing lizard: loss of variability in introduced populations of Podarcis sicula. Experientia, 50, 691-696.

CAPula, M. 1994c. Evolutionary relationships of Podarcis lizards from Sicily and the Maltese Islands. J. Zoo. Syst. Evol. Res., 32, 180-192.

ELSTON, R. C. AND FORTHOFER, R. 1977. Testing for Hardy-Weinberg equilibrium in small samples. Biometrics, 33, 536-542.

Gorman, G. C. AND KIM, Y. J. 1976. Anolis lizards of the eastern Caribbean: a case study in evolution. II. Genetic relationships and genetic variation of the bimaculatus group. Syst. Zool., 25, 62-77.

GORMAN, G. C., SOULÉ, M., YANG, S. Y. AND NEVO, E. 1975. Evolutionary genetics of insular Adriatic lizards. Evolution, 29, 52-71.

Guillaume, C.-P. AND LANZA, B. 1982. Comparaison electrophorétique de quelques espèces de Lacertidés Méditerranéens, Genera Podarcis et "Archaeolacerta". Amphibia-Reptilia, 4, 361-375.

HALDANE, J. B. S. 1954. An exact test for randomness of mating. J. Genet., 52, 631-635.

HARR1S, H. 1966. Enzyme polymorphisms in man. Proc. $R$. 
Soc., B, 164, 298-310.

HARRIS, H. AND HOPKINSON, D. A. 1976. Handbook of Enzyme Electrophoresis in Human Genetics. NorthHolland Publishing, Amsterdam.

KOEHN, R. K. AND EANES, W. F. 1978. Molecular structure and protein variation within and among populations. Evol. Biol., 11, 39-100.

LANZA, B. 1972. The natural history of the Cerbicale Islands (southeastern Corsica) with particular reference to their herpetofauna. Natura, 63, 185-202.

LANZA, B. 1983. Ipotesi sulle origini del popolamento erpetologico della Sardegna. Lav. S.I.B. (N.S.), 8 (1980), 723-744.

LANZA, B. AND POGgesi, M. 1986. Storia naturale delle isole satelliti della Corsica. L'Universo, 66, 2-197.

LANZA, B., CEI, J. M. AND CRESPO, E. G. 1977. Immunological investigations on the taxonomic status of some Mediterranean lizards (Reptilia Lacertidae). Monit. Zool. Ital. (N.S.), 11, 211-221.

LARSON, A., WAKE, D. B. AND YANEV, K. P. 1984. Measuring gene flow among populations having high levels of genetic fragmentation. Genetics, 106, 293-308.

LEVENE, H. 1949. On a matching problem arising in genetics. Ann. Math. Stat., 20, 91-94.

MCKINNEY, C. O., SELANDER, R. K., JOHNSON, W. E. AND YANG, S. Y. 1972. Genetic variation in the Side-blotched Lizard (Uta stansburiana). Studies in Genetics, VII. University of Texas Publication, 7213, 307-318.

MAYER, w. 1981. Elektrophoretische Untersuchungen an europäischen Arten der Gattungen Lacerta und Podarcis. III. Podarcis tiliguerta - Art oder Unterart? Zool. Anz., 207, 151-157.

MAYER, W. AND TIEDEMANN, F. 1982. Chemotaxonomical investigations in the collective genus Lacerta (Lacertidae, Sauria) by means of protein electrophoresis. Amphibia-Reptilia, 2, 349-355.

MAYER, W. AND TIEDEMANN, F. 1985. Heart-lactate dehydrogenase: an allozyme marker differentiating Lacerta trilineata Bedriaga, 1886, and Lacerta viridis (Laurenti, 1768) in Southern Europe. Amphibia-Reptilia , 6, 163-172.

NAGYLAKI, T. 1983. The robustness of neutral models of geographic variation. Theor. Pop. Biol., 74, 268.

NEI, M. 1972. Genetic distance between populations. Am. Nat., 106, 283-292.

NEI, M. 1978. Estimation of average heterozygosity and genetic distance from a small number of individuals. Genetics, 89, 583-590.

NEVo, E. 1978. Genetic variation in natural populations: patterns and theory. Theor. Pop. Biol., 13, 121-177.

RAGGHIANT1, M. AND WAKE, D. B. 1986. Genic variation and its evolutionary implications in the Italian newt, Triturus italicus. Herpetologica, 42, 206-214.

ROHLf, F. J. 1989. NTSYS-PC. Numerical Taxonomy and Multivariate Analysis System, version 1.50. Exeter Publishing, Setauket, NY.

SARRE, S., SCHWANER, T. D. AND GEORGES, A. 1990. Genetic variation among insular populations of the Sleepy Lizard, Trachydosaurus rugosus Gray (Squamata: Scinci- dae). Aust. J. Zool., 38, 603-616.

SCHONEWALD-COX, C. M., CHAMBERS, S. M., MACBRYDE, B. AND THOMAs, w. L. (eds) 1983. Genetics and Conservation: a Reference for Managing Wild Animal and Plant Populations. The Benjamin-Cummings Publishing Company, Menlo Park, CA.

SElANDER, R. K. AND WhitTMan, T. S. 1983. Protein polymorphism and the genetic strucutre of populations. In: Nei, M. and Koehn, R.K. (eds) Evolution of Genes and Proteins, pp. 89-114. Sinauer Associates, Sunderland, MA.

SELANDER, R. K., SMITH, M. H., YANG. S. Y., JOHNSON, W. E. AND GENTRY, J. B. 1971. Biochemical polymorphism and systematics in the genus Peromyscus. I. Variation in the old field mouse (Peromyscus polionotus). Studies in Genetics, VI. University of Texas Publication, 7103, 49-90.

SHAW, C. R. AND PRASAD R. 1970. Starch gel electrophoresis of enzymes - a compilation of recipes. Biochem. Genet., 4, 297-320.

SITES, J. W. AND GReenbaum, I. F. 1983. Chromosome evolution in the iguanid lizard Sceloporus grammicus. II. Allozyme variation. Evolution, 37, 54-65.

SLATKIN, M. 1987. Gene flow and the geographic structure of natural populations. Science, 236, 787-792.

SMOUSE, P. E., LONG, J. C. AND SOKAL, R. R. 1986. Multiple regression and correlation extensions of the Mantel test of matrix correspondence. Syst. Zool., 35, 627-632.

SNEATH, P. H. A. AND SOKAL, R. R. 1973. Numerical Taxonomy. W.H. Freeman, San Francisco.

SOKAL, R. A. AND ODEN, N. L. 1978. Spatial autocorrelation in biology. 1. Methodology. Biol. J. Linn. Soc., 10, 199-228.

SwOFFord, D. L. AND SELANDER, R. B. 1981. BIOSYs-1. A Fortran program for the comprehensive analysis of electrophoretic data in population genetics and systematics. J. Hered., 72, 281-283.

THORPE, J. P. 1983. Enzyme variation, genetic distance and evolutionary divergence in relation to levels of taxonomic separation. In: Oxford, G.S. and Rollinson, D. (eds) Protein Polymorphism: Adaptive and Taxonomic Significance, Systematics Association Special Volume 24, pp. 131-152. Academic Press, London.

WILSON, E. o. 1961. The nature of the cycle in the Melanesian ant fauna. Am. Nat., 95, 165-193.

WORKMAN, P. L. AND NISWANDER, J. D. 1970. Population studies on southwestern Indian tribes. II. Local genetic differentiation in the Papago. Am. J. Hum. Genet., 22, 24-49.

WRIGHT, s. 1940. Breeding structure of populations in relation to speciation. Am. Nat., 74, 232-248.

WRIGHT, s. 1943. Isolation by distance. Genetics, 28 , 114-138.

WRIGHT, s. 1965. The interpretation of population structure by F-statistics with special regard to systems of mating. Evolution, 19, 395-420.

WRIGHT, s. 1978. Evolution and the Genetics of Populations, vol. 4, Variability Within and Among Natural Populations. University of Chicago Press, Chicago. 


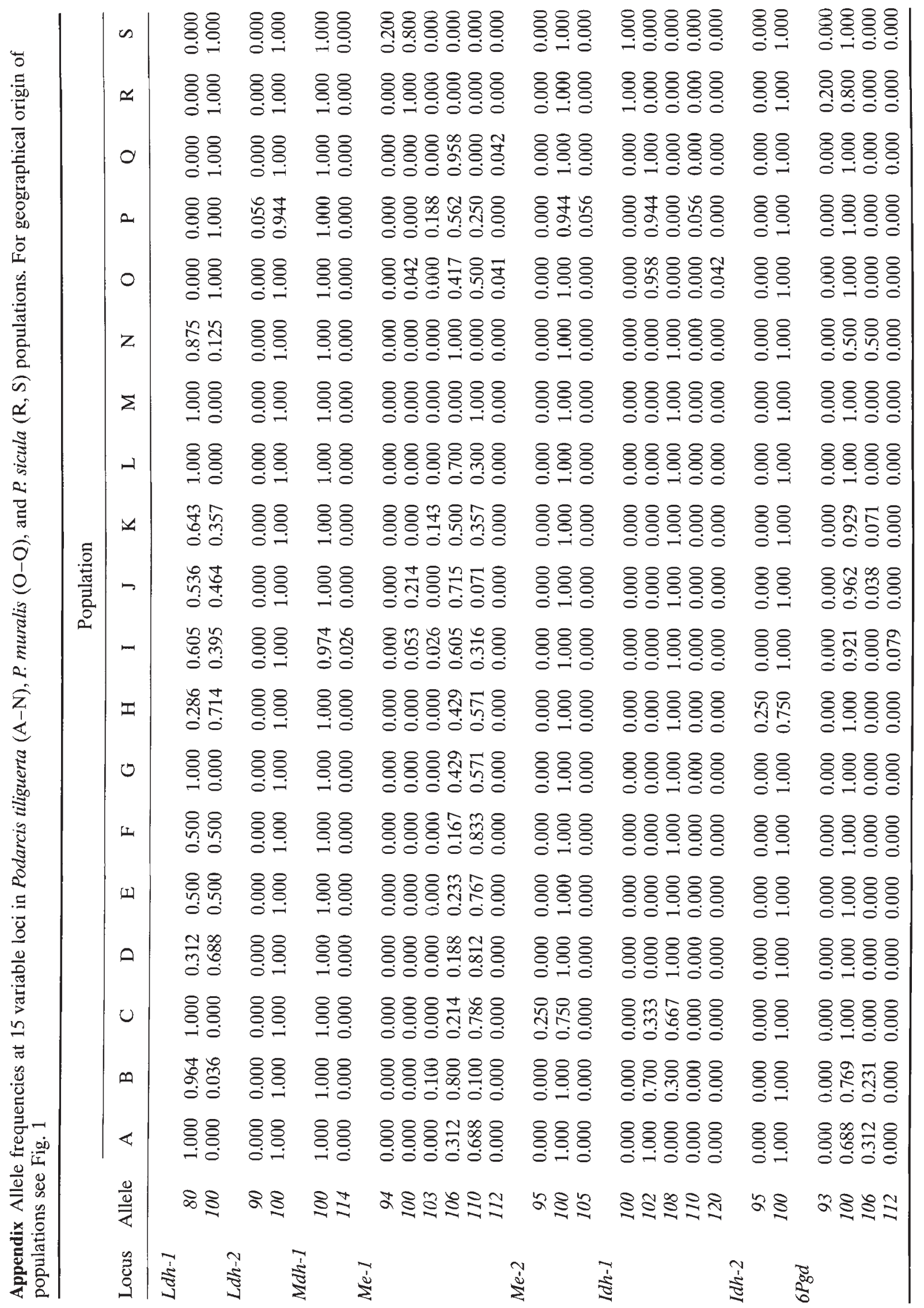




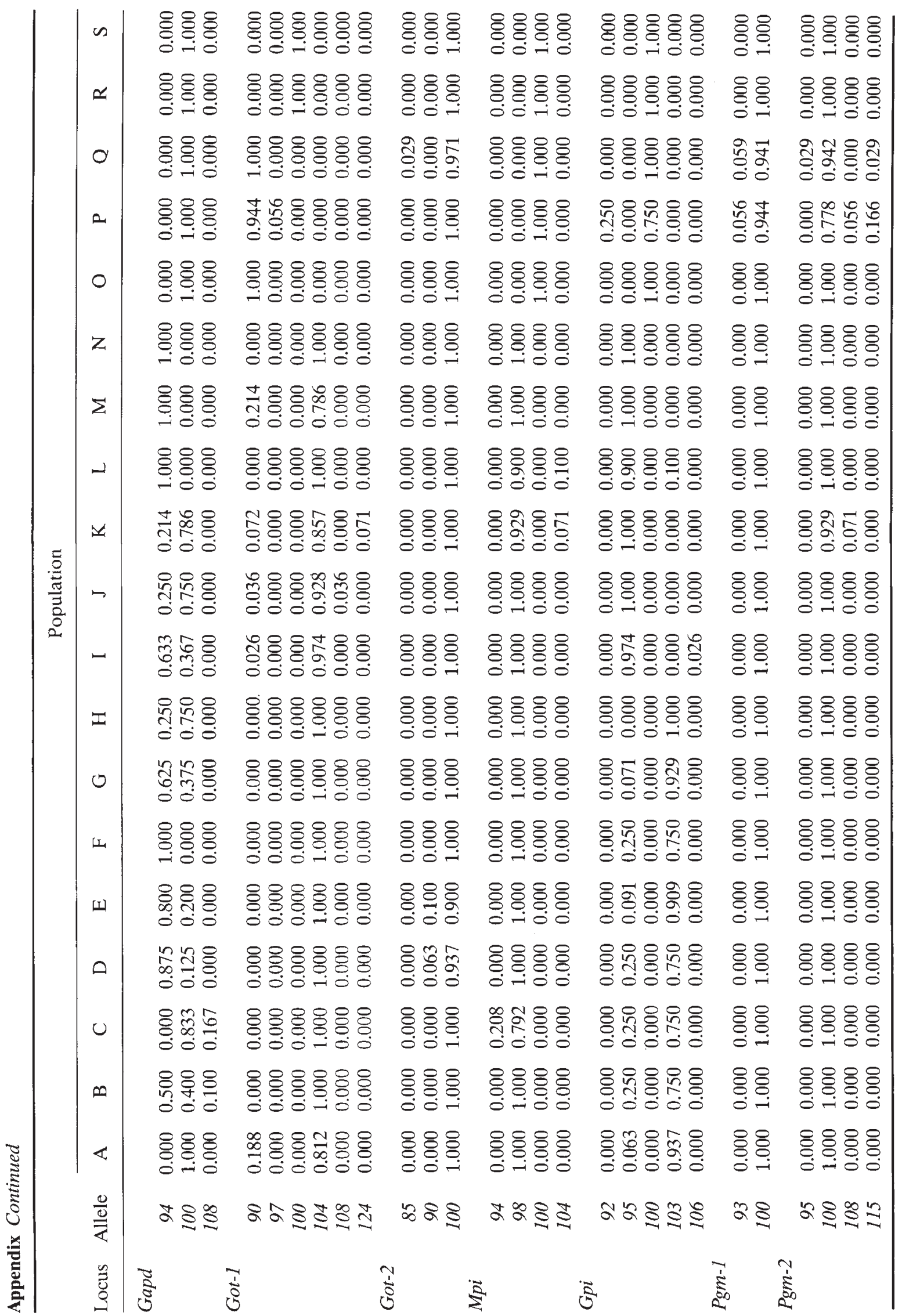

